\title{
Transforming Growth Factor Alpha Stimulation of Mucosal Tissue Cultures from Head and Neck Squamous Cell Carcinoma Patients Increases Chemoresistance to Cisplatin
}

\author{
Philipp Baumeister $^{\mathrm{a}}$ Maximilian Reiter ${ }^{\mathrm{a}}$ Sabina Schwenk-Zieger ${ }^{\mathrm{b}}$ \\ Ulrich Harréus ${ }^{\text {a }}$ \\ ${ }^{a}$ Department of Otolaryngology and Head and Neck Surgery, and ${ }^{b}$ Clinical Experimental Oncology, \\ Department of Otolaryngology and Head and Neck Surgery, Ludwig Maximilian University, Munich, Germany
}

\section{Key Words}

Chemoresistance to cisplatin - Transforming growth factor $\alpha$ stimulation $\cdot$ Head and neck squamous cell carcinoma

\begin{abstract}
The monoclonal epidermal growth factor receptor (EGFR) antibody cetuximab (Erbitux' ${ }^{\mathrm{TM}}$ ) was recently approved by the European Medicines Agency for the treatment of recurrent and/or metastatic head and neck squamous cell carcinoma (HNSCC) in combination with a platinum-based chemotherapy. Since the antibody has only a limited effect as a monotherapy, possible explanations for the synergistic effect with cisplatin are enhanced antibody-dependent cytoxicity and increased sensitivity to the drug. Most of our knowledge of EGFR biology in HNSCC is based on studies using EGFR inhibitors and/or antibodies. Our study was designed to evaluate the impact of EGFR stimulation on cisplatin-induced DNA damage. Therefore, tissue cultures were produced of tumor-free oropharyngeal mucosa biopsies of HNSCC patients and controls. In a previous study, overexpression of EGFR in tissue cultures from tumor patients compared to controls was confirmed by immunohistochemical staining. Twenty-four-hour stimulation of tissue cultures with transforming growth factor $\alpha$ (TGF- $\alpha$ ), a specific EGFR
\end{abstract}

ligand, resulted in a reduction of cisplatin-induced DNA damage by $35 \%$ in cases, whereas in controls TGF- $\alpha$ had no effect. This reflects a statistically significant increase in cellular chemoresistance to cisplatin following TGF- $\alpha$ stimulation and helps to further understand effects of EGFR antisense therapy in combination with chemotherapy.

Copyright $\odot 2010$ S. Karger AG, Basel

\section{Introduction}

Epidermal growth factor receptor (EGFR)-targeting therapeutics represent a major improvement in the treatment of recurrent or metastatic squamous cell carcinoma in the head and neck (HNSCC). The rationale behind this is based on several findings:

(a) the inhibition of EGFR signaling was shown to effectively decrease the proliferation rate using various EGFR-overexpressing cell lines [1];

(b) HNSCC exhibits EGFR overexpression in up to $90 \%$ of tumors [2];

The results of this study were partially presented at the 80th annual meeting of the German Society of Otorhinolaryngology, Head and Neck Surgery.

\section{KARGER}

Fax +41613061234 E-Mail karger@karger.ch www.karger.com (c) 2010 S. Karger AG, Basel

0009-3157/10/0564-0268\$26.00/0

Accessible online at:

www.karger.com/che
Philipp Baumeister, MD

Department of Otolaryngology and Head and Neck Surgery

Ludwig Maximilian University, Marchioninistrasse 15

DE-81377 Munich (Germany), Tel. +49 897095 0, Fax +49 8970956869

E-Mail philipp.baumeister@med.uni-muenchen.de 
(c) somatic mutations of EGFR gene are frequently found in HNSCC $[3,4]$;

(d) EGFR expression level seems to be correlated with poor prognosis of cancer patients [5].

While cetuximab (Erbitux ${ }^{\mathrm{TM}}$ ) has only limited efficacy as a monotherapeutic approach $[2,5]$, the monoclonal EGFR antibody was approved by the EMEA (European Medicines Agency ${ }^{1}$ ) and FDA (Food and Drug Administration, $\mathrm{USA}^{2}$ ) for the treatment of locally advanced HNSCC when combined with radiotherapy. Drugs targeting EGFR intrinsic tyrosine kinase like erlotinib $\left(\right.$ Tarceva $\left.^{\mathrm{TM}}\right)$ are currently under clinical investigation for the treatment of HNSCC.

In this context, it is important to note that the development of EGFR antisense therapeutics was widely based on observations made after EGFR inhibition. Cetuximab was shown to inhibit cell proliferation and decrease cell survival, to reduce cellular motility and tumor invasion and to diminish angiogenesis in various tumor models [6-10].

EGFR activation, on the other hand, did not lead to consistent results. In a recent study, Song et al. [11] could show that EGF induces apoptosis in 3 carcinoma cell lines and that the ligand has more cytotoxic potential than EGFR blockers in these receptor-overexpressing cell lines. Studies showing that ligand-induced EGFR activation leads to apoptosis are reviewed by Danielsen and Maihle [12]. As summarized by McCubrey et al. [13], what they call 'fine-tuning' of the Raf/MEK/ERK signal transduction pathway, which lies downstream of EGFR activation, dictates whether there will be cell cycle arrest or proliferation. In the future, further understanding of this 'fine-tuning' will help to develop more specific inhibitors of signal transducers like rapamycin [14].

Recently, Vermorken et al. [15] reported the efficacy of cetuximab in combination with a platinum-based chemotherapy as first-line treatment of recurrent or metastatic HNSCC. Possible explanations for the synergistic effects include enhanced antibody-dependent cytotoxicity and enhanced chemosensitivity $[16,17]$.

It is an important feature of EGFR biology in HNSCC that the receptor is continuously activated by EGF-related growth factors produced by either the tumor cells them-

\footnotetext{
1 http://www.emea.europa.eu/humandocs/PDFs/EPAR/erbitux/H-558II-26-AR.pdf. December 19, 2008.

2 http://www.fda.gov/AboutFDA/CentersOffices/CDER/ucm095662. htm.
}

selves or surrounding stromal cells [18]. Interestingly, increased expression of EGFR and its specific ligand transforming growth factor $\alpha$ (TGF- $\alpha$ ) was detected in histologically normal mucosa of HNSCC patients compared to non-tumor patients [19].

Our study evaluates the impact of TGF- $\alpha$ stimulation of human mucosal tissue cultures of tumor and control patients on cisplatin-induced DNA damage using the alkaline single-cell microgel electrophoresis (comet) assay.

\section{Materials and Methods}

\section{Mini-Organ Cultures}

The study was approved by the ethics committee of Ludwig Maximilian University, Munich, Germany (project 349-05). All biopsy donors were informed by the investigators and signed an informed consent statement.

We prepared mini-organ cultures (MOC) from fresh biopsied oropharyngeal mucosa samples from tumor and control patients. Samples were harvested during resection of oropharyngeal squamous cell carcinomas and tonsillectomy, respectively. Biopsies of tumor patients were taken from macroscopically normal mucosa close to the tumor-free resection margins. In a previous study, EGFR overexpression of MOC from tumor patients was confirmed by immunohistochemical staining (data not shown).

Specimens were dissected into cubes of $1 \mathrm{~mm}^{3}$ excluding deeper layers and washed three times in bronchial epithelial cell basal medium (BEGM; supplemented with bovine pituitary extract, insulin, hydrocortisone, epinephrine, triiodothyronine, transferrin and retinoic acid; Promocell, Heidelberg, Germany). Cubes were placed in 24-well plates, 1 each well, and coated with $0.75 \%$ Agar Noble (Difco, Detroit, Mich., USA) and dissolved in Dulbecco's modified Eagle's medium (Gibco, Eggenstein, Germany), 10\% fetal calf serum (Gibco), nonessential amino acids (Gibco) and amphotericin B (Gibco). After about 20 days in $250 \mu$ l BEGM, each well at $37.5^{\circ} \mathrm{C}, 5 \% \mathrm{CO}_{2}$ and $100 \%$ relative humidity, MOC were completely coated with epithelium. BEGM was replaced every second day during cultivation. Every seventh day, multiwell plates were changed to avoid adherence [20]. As seen in figure 1, after complete epithelialization, the majority of cells within the MOC is of epithelial origin, and there is only a limited number of stromal cells, vessels and glands. The model of MOC has several advantages compared to cell line experiments or animal models. In MOC, cells stay in their original surrounding tissue, which might have an impact on their metabolic competence [21, 22]. Furthermore, standardized conditions can be applied. However, during the culturing process, additional oxidative stress and DNA damage occurs [23].

\section{Cisplatin-Induced DNA Damage}

Cisplatin is well known to produce interstrand cross-links within the DNA. Since the alkaline single-cell microgel electrophoresis assay is able to detect DNA strand breaks, hydrogen peroxide $\left(\mathrm{H}_{2} \mathrm{O}_{2}\right)$ was used to introduce random DNA fragmentation. Therefore, cisplatin-induced DNA cross-links reduced migration of DNA fragments compared to untreated DNA as measured with the comet assay [24]. 
Fig. 1. Histological slide of an MOC (control group; hematoxylin/eosin staining, $\times 500)$ showing the continuous epithelium and the underlying connective tissue with small vessels and glands.

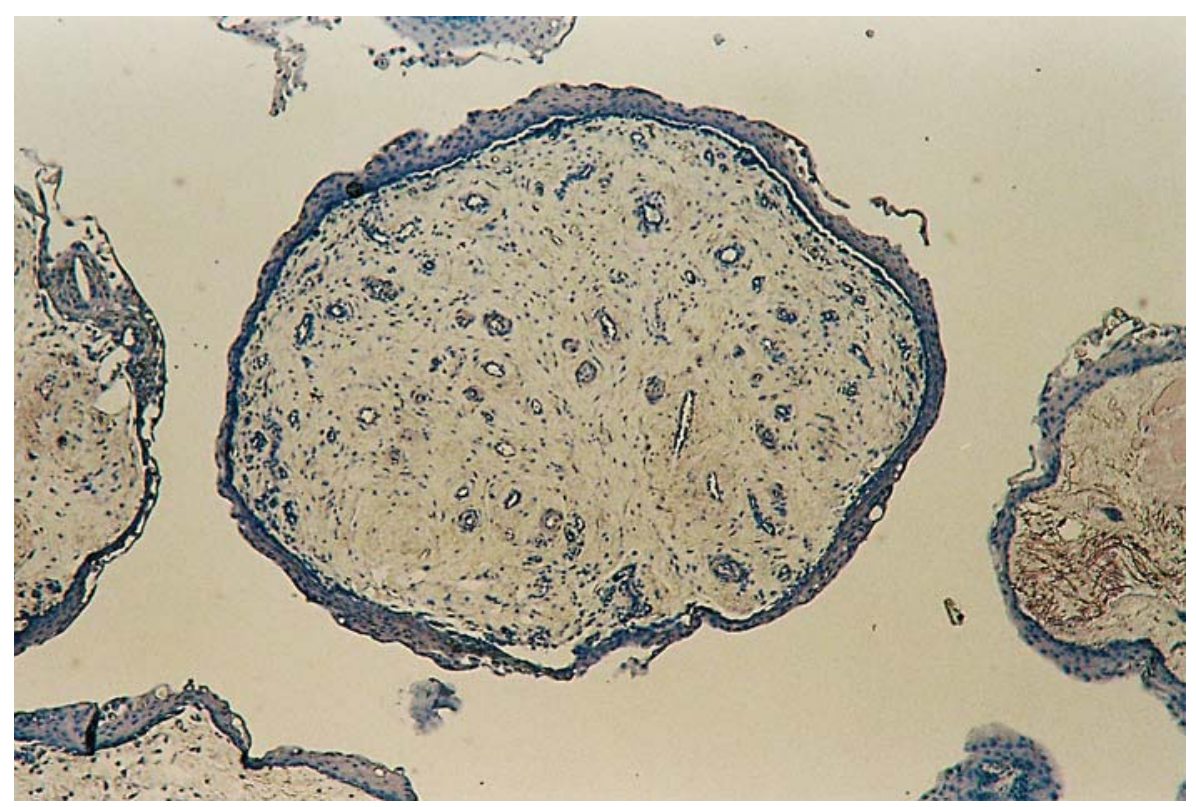

MOC were stimulated with TGF- $\alpha(100 \mathrm{ng} / \mathrm{ml})$ dissolved in dimethyl sulfoxide (DMSO; Merck, Darmstadt, Germany) for $24 \mathrm{~h}$. MOC were then washed twice before incubation with cisplatin (10 $\mathrm{MM}$; dissolved in DMSO) for another $24 \mathrm{~h}$. This concentration was previously shown to induce sufficient DNA crosslinks without inducing apoptosis in cell cultures [24]. Thereafter, $\mathrm{H}_{2} \mathrm{O}_{2}(1 \mathrm{~mm})$ induced random DNA fragmentation within 15 min. MOC were finally washed again twice. All incubations were carried out at $37.5^{\circ} \mathrm{C}, 5 \% \mathrm{CO}_{2}$ and $100 \%$ relative humidity.

Alkaline Single-Cell Microgel Electrophoresis (Comet) Assay

MOC were digested enzymatically thus gaining single cells. As stated before, the majority of these cells are epithelial cells [20]. Enzyme suspension included collagenase P (Boehringer, Mannheim, Germany; $1 \mathrm{mg} / \mathrm{ml}$ ), hyaluronidase (Boehringer; $1 \mathrm{mg} / \mathrm{ml}$ ) and protease (Sigma; $5 \mathrm{mg} / \mathrm{ml}$ ). MOC were suspended for $60 \mathrm{~min}$ at $37.5^{\circ} \mathrm{C}$. After neutralizing histolytic enzymes with fetal calf serum (Gibco), single cells were washed twice in cold phosphate-buffered saline (Gibco), followed by trypan blue exclusion test to monitor cell viability.

Single cells were resuspended in $75 \mu \mathrm{l} 0.7 \%$ low-melting agarose (FMC Bioproducts, Rockland, Me., USA) and the suspension was evenly distributed on slides between 2 layers of $85 \mu \mathrm{l} 0.5 \%$ normal-melting agarose (FMC Bioproducts). For better adhesion, slides had $5 \mathrm{~mm}$ frosted edges. Lysis of cellular and nuclear membranes was performed under alkaline conditions in a solution containing 2.5 M NaCl (Sigma), $10 \mathrm{~mm}$ Trizma base (Merck), 100 $\mathrm{mM} \mathrm{Na}_{2}$ EDTA (Serva, Heidelberg, Germany) and 1\% N-lauroylsarcosine sodium salt (Sigma) at pH 10, with 1\% Triton X-100 (Sigma) and 10\% DMSO (Merck) added just before use. Subsequently, slides were positioned in a horizontal electrophoresis chamber (Renner, Dannstadt, Germany), close to the anode. Slides were covered with a $4^{\circ} \mathrm{C}$ cold alkaline buffer solution ( $\mathrm{pH}$ 13.2) consisting of $300 \mathrm{~mm} \mathrm{NaOH}$ (Merck) and $1 \mathrm{mM} \mathrm{Na}_{2}$ EDTA (Serva).
The DNA unwinded for 20 min before migration within an electric field ( $25 \mathrm{~V}, 1.0 \mathrm{~V} / \mathrm{cm}, 300 \mathrm{~mA}, 20 \mathrm{~min})$. Alkaline buffer was now neutralized with Trizma base solution (Merck; $400 \mathrm{mM}$, $\mathrm{pH}$ 7.5). Fluorescent DNA staining was performed with $75 \mu \mathrm{l}$ ethidium bromide (Sigma). After staining, slides were analyzed with a DMLB microscope (Leica, Bensheim, Germany). Eighty cell nuclei per slide were selected at random and digitized with the attached monochrome CCD camera (Cohu Inc., San Diego, Calif., USA). DNA migration was measured by the image analysis software Komet++ (Kinetic Imaging, Liverpool, UK) using olive tail moments (OTM). OTM represents the multiplication of the relative amount of DNA in the tail with the median migration distance and is commonly used to measure comet assay results not giving any units.

\section{Statistical Analysis}

Significant differences in DNA damage between the samples were calculated by the Friedman test using SPSS 16.0 software (SPSS GmbH, Munich, Germany). Calculation was based on the arithmetic mean of 80 OTM of each slide; the $\alpha$ level was set at 0.05 prior to statistical analysis.

\section{Results}

After all treatments, cell viability was $>90 \%$ as assessed by the trypan blue exclusion test.

The solvent DMSO served as negative control and average OTM was 0.74 in controls and 0.86 in cases, reflecting minor DNA damage occurring during the cultivation process [25]. As expected, cisplatin did not lead to detectable DNA fragmentation using the alkaline version of the 
Fig. 2. DNA damage (mean OTM) induced by the solvent DMSO and cisplatin without/with prior stimulation of MOC with TGF- $\alpha$ for $24 \mathrm{~h}(\mathrm{n}=20$, except tumor cisplatin: $\mathrm{n}=19 ;^{\circ}=$ extreme value; ${ }^{*}=$ outlier).

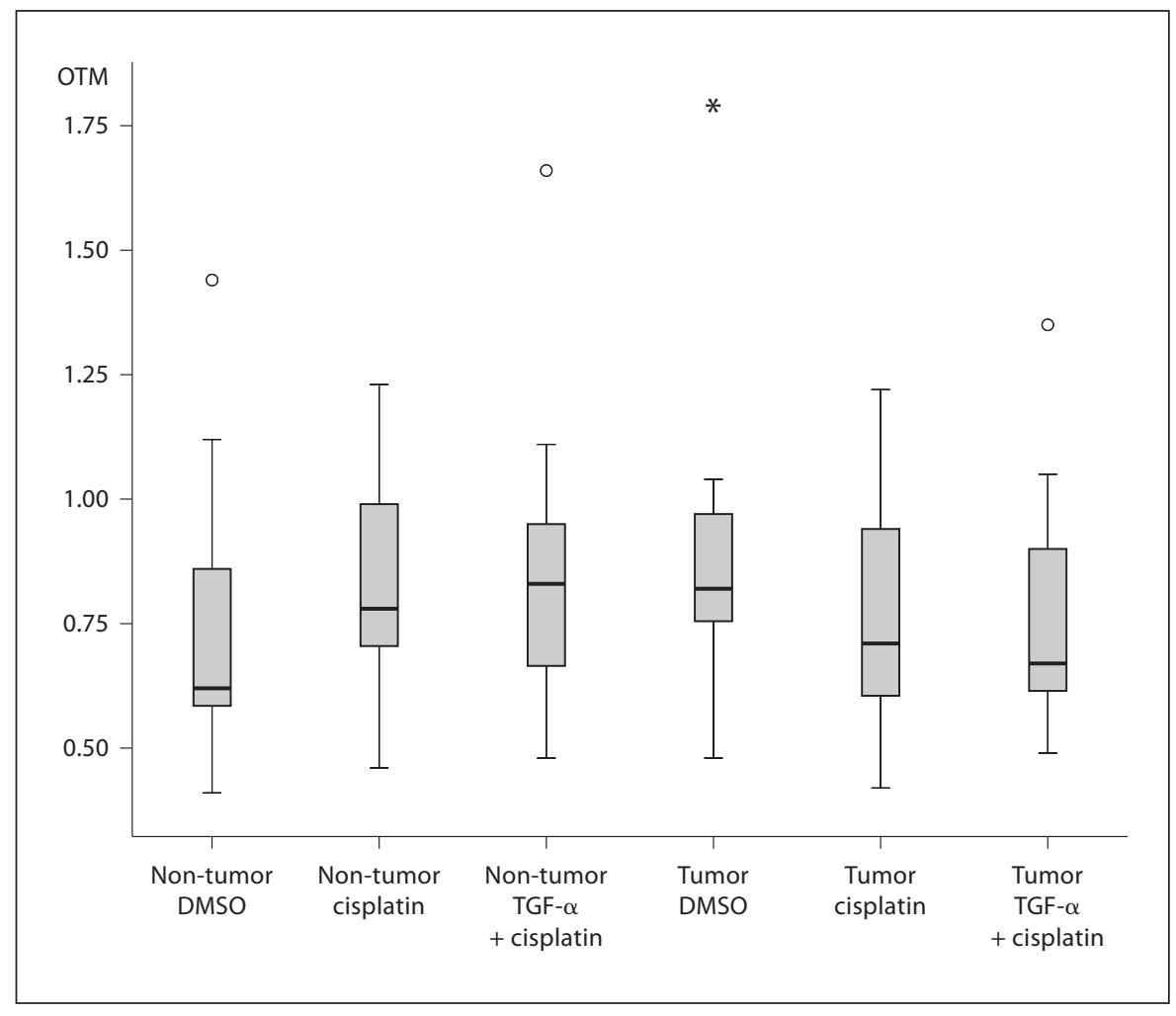

comet assay. OTM was 0.84 , with and without preliminary stimulation with TGF- $\alpha$ in the non-tumor group. In cases, OTM was 0.77 without, and 0.76 after TGF- $\alpha$ stimulation (fig. 2).

In controls, $\mathrm{H}_{2} \mathrm{O}_{2}$ caused DNA damage with an average OTM of 9.7, which is statistically significant compared to negative control $(\mathrm{p}<0.001)$. Stimulation with TGF- $\alpha$ did not significantly change $\mathrm{H}_{2} \mathrm{O}_{2}$-induced DNA fragmentation, which is reflected by OTM 8.8. To evaluate cisplatin-induced DNA cross-links, the introduction of random DNA strand breaks is necessary. Therefore, MOC were incubated with $\mathrm{H}_{2} \mathrm{O}_{2}$ for $15 \mathrm{~min}$. Lower OTM values then reflect higher levels of cisplatin-induced cross-links as linked DNA hardly dissociates during electrophoresis [24]. In controls, after prior incubation with cisplatin, average OTM due to $\mathrm{H}_{2} \mathrm{O}_{2}$-induced DNA fragmentation was 4.35. Compared to OTM 9.7 without pretreatment with cisplatin, this shows significant cross-linking levels $(\mathrm{p}<0.001)$. In this group, previous stimulation of MOC with TGF- $\alpha$ for $24 \mathrm{~h}$ did not significantly alter DNA cross-linking by cisplatin (OTM = 4.23; fig. 3).

In cases, DNA damage caused by $\mathrm{H}_{2} \mathrm{O}_{2}$ was not influenced by TGF- $\alpha$ stimulation. OTM induced by $\mathrm{H}_{2} \mathrm{O}_{2}$ sig- nificantly decreased from 12.5 to 5.9 when MOC were previously treated with cisplatin due to cross-linking $(\mathrm{p}<0.001)$. Here, 24-hour stimulation with TGF- $\alpha$ before adding cisplatin significantly reduced DNA cross-links, which is reflected in increased OTM to 8 ( $\mathrm{p}=0.025$; fig. 4).

\section{Discussion}

Our results show that TGF- $\alpha$ effectively reduces the ability of cisplatin to induce DNA cross-links. This effect could only be shown in MOC produced from macroscopically normal oropharyngeal mucosa samples of tumor patients, whereas TGF- $\alpha$ had no impact on $\mathrm{H}_{2} \mathrm{O}_{2}$-induced DNA fragmentation in controls. TGF- $\alpha$ had no effect on DNA damage induced by $\mathrm{H}_{2} \mathrm{O}_{2}$ in either group.

Cisplatin forms interstrand cross-link adducts on DNA, it interferes with DNA synthesis and activates cell death pathways [26]. Therefore, possible explanations for our observation would be the reduction of cross-link formation by reduced intracellular accumulation. Cisplatin enters the cell mostly by passive diffusion, although active transportation might facilitate intracellular accumu- 


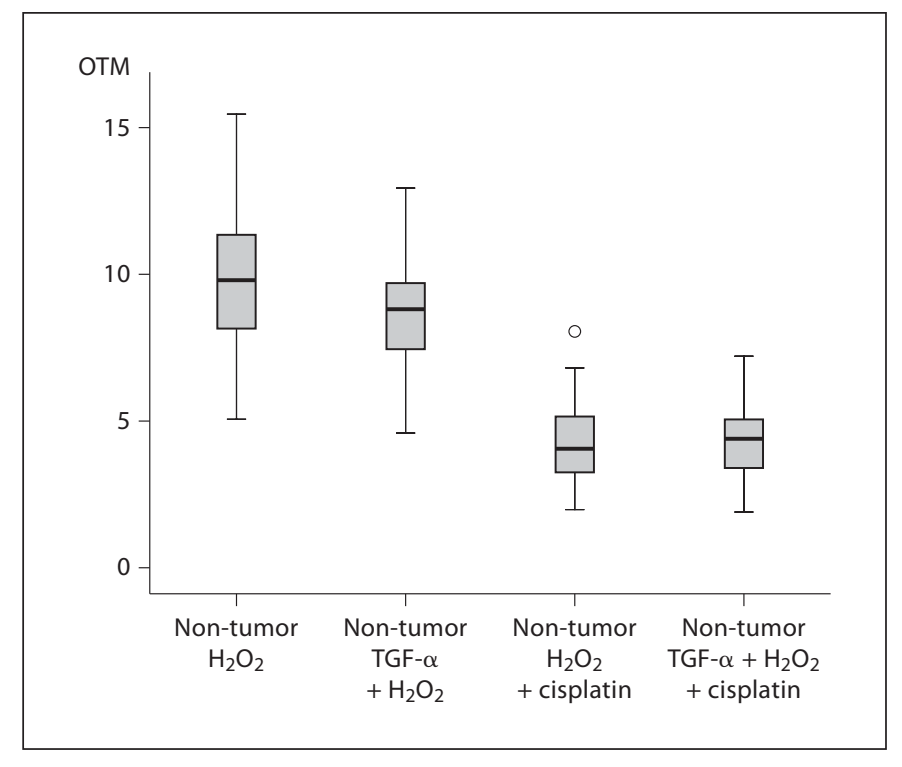

Fig. 3. DNA damage (mean OTM) caused by hydrogen peroxide and DNA cross-linking by cisplatin with/without prior stimulation of MOC with TGF- $\alpha$ for $24 \mathrm{~h}$ in controls $\left(\mathrm{n}=20 ;^{\circ}=\right.$ extreme value).

lation [27]. Inside the cell, cisplatin is believed to react with a multitude of non-DNA targets, such as proteins and the cytoskeleton. The most important non-DNA target is glutathione [28]. Cell line experiments showed inversely correlated intracellular glutathione levels and cisplatin sensitivity [29]. Furthermore, there seems to be a connection between extracellular ATP levels and cytotoxic effects of cisplatin [30].

More recently, transporter proteins of the $\mathrm{ABC}$ family on the cellular surface were shown to confer drug resistance $[31,32]$. There is growing evidence that cisplatin is a substrate of efflux pumps on the plasma membrane, extruding the drug from the cell. This happens in two phases. The so-called phase 0 'preemptive pumping' describes the elimination of cisplatin before it can react with cellular components immediately after entering the cell. The multidrug resistance protein 2 (cMoat) was shown to confer resistance to cisplatin [33] and overexpression of multidrug resistance protein 2 has been described in at least 1 cisplatin-resistant cell line [34]. In addition, after conjugation with glutathione, the complex is a substrate of the glutathione S-conjugate efflux pump [35] during phase 3 metabolism.

The exact mechanism of how TGF- $\alpha$ stimulation altered cisplatin sensitivity in our study remains unclear. Since the growth factor had no influence on $\mathrm{H}_{2} \mathrm{O}_{2}$-in-

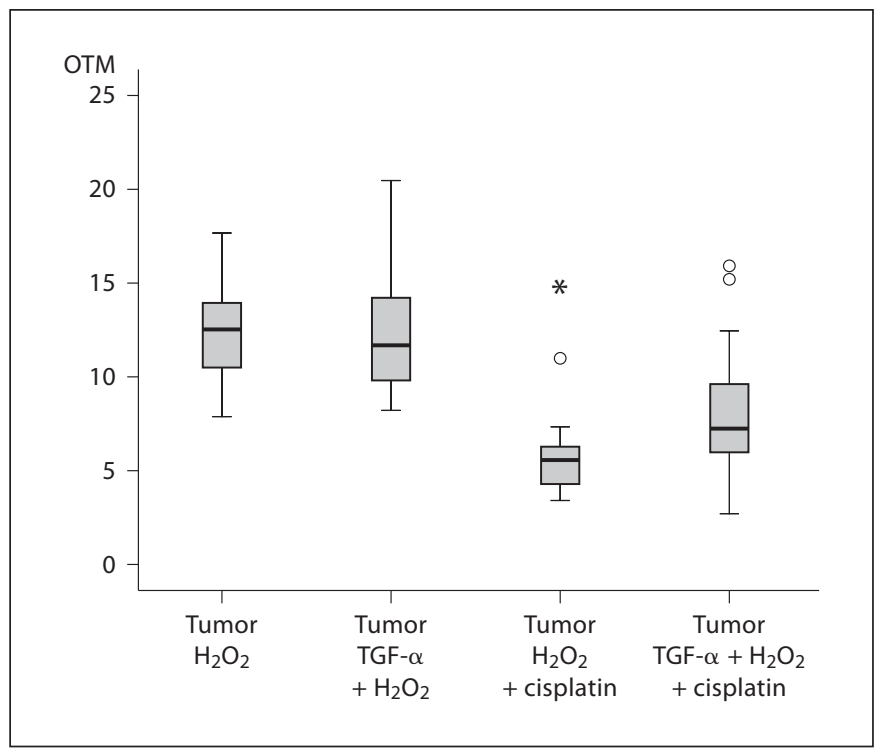

Fig. 4. DNA damage (mean OTM) caused by hydrogen peroxide and DNA cross-linking by cisplatin with/without prior stimulation of MOC with TGF- $\alpha$ for $24 \mathrm{~h}$ in cases $\left(\mathrm{n}=20 ;^{\circ}=\right.$ extreme value; ${ }^{*}=$ outlier).

duced DNA fragmentation, major effects on cellular glutathione levels are unlikely. In a previous study in our laboratory, MOC were incubated with benzo(a)pyrene diol epoxide, a well-established carcinogen, that - like cisplatin - forms DNA adducts. Benzo(a)pyrene diol epoxide is likewise detoxified via conjugation with glutathione. In this study, TGF- $\alpha$ did not affect DNA repair capacity [36].

There is increasing evidence that EGFR downstream signaling pathways play a major role in the development of chemoresistance, even though experimental results are in part contradictory. While Garcia et al. [37] showed that stimulation of MCF-7 breast cancer cells with EGF (a specific EGFR ligand) induced the expression of genes involved in drug resistance, Mandic et al. [38] found that cisplatin resistance of UT-SCC-26A head and neck cancer cells can be overcome after EGF stimulation. Using the same cell line, the latter group previously showed that EGFR inhibition by cetuximab significantly reduces cisplatin $\mathrm{IC}_{50}$ [39].

In contrast to most studies evaluating the influence of EGFR signaling in cisplatin resistance using cell lines and animal models, we used freshly biopsied tissue samples. Our results clearly show that simulation with TGF- $\alpha$, a specific EGFR ligand [40], significantly reduces the ability of cisplatin to form DNA cross-links in MOC pro- 
duced of macroscopically normal mucosa of HNSCC patients, which was previously shown to overexpress EGFR [19]. Immunohistochemical staining of MOC slides from these patients in our laboratory confirmed this finding (data not shown). The results presented here are consis- tent with clinical studies that showed the benefit of EGFR targeting in combination with a platinum-based chemotherapy [15]. Possible influence of TGF- $\alpha$ on the expression and/or function of cisplatin efflux pumps are currently under investigation in our laboratory.

\section{References}

1 Bos M, Mendelsohn J, Kim YM, Albanell J, Fry DW, Baselga J: PD153035, a tyrosine kinase inhibitor, prevents epidermal growth factor receptor activation and inhibits growth of cancer cells in a receptor numberdependent manner. Clin Cancer Res 1997;11: 2099-2106.

2 Kalyankrishna S, Grandis JR: Epidermal growth factor biology in head and neck cancer. J Clin Oncol 2006;24:2666-2672.

3 Lee JW, Soung YH, Kim SY: Somatic mutations of EGFR gene in squamous cell carcinoma of the head and neck. Clin Cancer Res 2005; 11:2879-2883.

4 Nishio K, Arao T, Kato T: EGFR mutation in various tissue. Cancer Chemother Pharmacol 2006;58:S39-S41.

5 Ang KK, Berkey BA, Tu X, Zhang HZ, Katz R, Hammond EH, Fu KK, Milas L: Impact of epidermal growth factor receptor expression on survival and pattern of relapse in patients with advanced head and neck carcinoma. Cancer Res 2002;62:7350-7356.

6 Bernier J: Cetuximab in the treatment of head and neck cancer. Expert Rev Anticancer Ther 2006;6:1539-1552.

7 Bonner JA, Raisch KP, Trummell HQ, Robert F, Meredith RF, Spencer SA, Buchsbaum DJ, Saleh MN, Stackhouse MA, LoBuglio AF, Peters GE, Carroll WR, Waksal HW: Enhanced apoptosis with combination C225/ radiation treatment serves as the impetus for clinical investigation in head and neck cancers. J Clin Oncol 2000;18:47S-53S.

8 Peng D, Fan Z, Lu Y, DeBlasio T, Scher H, Mendelsohn J: Anti-epidermal growth factor receptor monoclonal antibody 225 up-regulates $\mathrm{p} 27 \mathrm{KIP} 1$ and induces G1 arrest in prostatic cancer cell line DU145. Cancer Res 1996;56:3666-3669.

9 Huang SM, Li J, Harari PM: Molecular inhibition of angiogenesis and metastatic potential in human squamous cell carcinomas after epidermal growth factor receptor blockade. Mol Cancer Ther 2002;1:507-514.

10 Perrotte P, Matsumoto T, Inoue K, Kuniyasu H, Eve BY, Hicklin DJ, Radinsky R, Dinney $\mathrm{CP}$ : Anti-epidermal growth factor receptor antibody C225 inhibits angiogenesis in human transitional cell carcinoma growing orthotopically in nude mice. Clin Cancer Res 1999;5:257-262.
11 Song JY, Lee SW, Hong JP, Chang SE, Choe $\mathrm{H}$, Choi J: Epidermal growth factor competes with EGF receptor inhibitors to induce cell death in EGFR-overexpressing tumor cells. Cancer Lett 2009;283:135-142.

12 Danielsen AJ, Maihle NJ: The EGF/ErbB receptor family and apoptosis. Growth Factors 2002;20:1-15.

13 McCubrey JA, Steelman LS, Chappell WH, Abrams SL, Wong EW, Chang F, Lehmann B, Terrian DM, Milella M, Tafuri A, Stivala F, Libra M, Basecke J, Evangelisti C, Martelli AM, Franklin RA: Roles of the Raf/MEK/ ERK pathway in cell growth, malignant transformation and drug resistance. Biochim Biophys Acta 2007;1773:1263-1284.

14 Aissat N, Le Tourneau C, Ghoul A, Serova M, Bieche I, Lokiec F, Raymond E, Faivre S: Antiproliferative effects of rapamycin as a single agent and in combination with carboplatin and paclitaxel in head and neck cancer cell lines. Cancer Chemother Pharmacol 2008;62:305-313.

15 Vermorken JB, Mesia R, Rivera F, Remenar E, Kawecki A, Rottey S, Erfan J, Zabolotnyy D, Kienzer HR, Cupissol D, Peyrade F, Benasso M, Vynnychenko I, De Raucourt D, Bokemeyer C, Schueler A, Amellal N, Hitt R: Platinum-based chemotherapy plus cetuximab in head and neck cancer. N Engl J Med 2009;359:1116-1127.

16 Kawaguchi Y, Kono K, Mimura K, Sugai H, Akaike H, Fujii H: Cetuximab induce antibody-dependent cellular cytotoxicity against EGFR-expressing esophageal squamous cell carcinoma. Int J Cancer 2007;120:781-787.

17 Hasegawa Y, Goto M, Hanai N, Ijichi K, Terada A, Hyodo I, Ogawa T, Fukushima M: Prediction of chemosensitivity using multigene analysis in head and neck squamous cell carcinoma. Oncology 2007;73:104-111.

18 Salomon DS, Brandt R, Ciardiello F, Normanno N: Epidermal growth factor-related peptides and their receptors in human malignancies. Crit Rev Oncol Hematol 1995;19: 183-232.

19 Rubin Grandis J, Melhem MF, Barnes EL, Tweardy DJ: Quantitative immunohistochemical analysis of transforming growth factor-alpha and epidermal growth factor receptor in patients with squamous cell carcinoma of the head and neck. Cancer 1996;78: 1284-1292.
20 Kleinsasser NH, Juchhoff J, Wallner BC, Bergner A, Harréus UA, Gamarra F, Bührlen M, Huber RM, Rettenmeier AW: The use of mini-organ cultures of human upper aerodigestive tract epithelia in ecogenotoxicology. Mutat Res 2004;561:63-73.

21 Teissier E, Fennrich S, Strazielle N, Daval JL, Ray D, Schlosshauer B, Ghersi-Egea JF: Drug metabolism in in vitro organotypic and cellular models of mammalian central nervous system: activities of membrane-bound epoxide hydrolase and NADPH-cytochrome P-450 (c) reductase. Neurotoxicology 1998; 19:347-355.

22 Schmeichel KL, Bissell MJ: Modeling tissuespecific signaling and organ function in three dimensions. J Cell Sci 2003;116:23772388.

23 Halliwell B, Whiteman M: Measuring reactive species and oxidative damage in vivo and in cell culture: how should you do it and what do the results mean? Br J Pharmacol 2004;142:231-255.

24 Blasiak J, Kowalik J, Małecka-Panas E, Drzewoski J, Wojewódzka M: DNA damage and repair in human lymphocytes exposed to three anticancer platinum drugs. Teratog Carcinog Mutagen 2000;20:119-131.

25 Harréus U, Schmezer P, Kuchenmeister F, Maier H: Genotoxic effect of human mucous membrane biopsies of the upper aerodigestive tract. Laryngorhinootologie 1999;78: $176-181$.

26 Siddik ZH: Cisplatin: mode of cytotoxic action and molecular basis of resistance. Oncogene 2003;22:7265-7279.

27 Perez RP: Cellular and molecular determinants of cisplatin resistance. Eur J Cancer 1998;34:1535-1542.

28 Reedijk J: Why does cisplatin reach guanineN7 with competing S-donor ligands available in the cell? Chem Rev 1999;99:24992510.

29 Yellina SA, Davidson BJ, Pinto JT, Sacks PG, Qiao C, Schantz SP: Relationship of glutathione and glutathione-S-transferase to cisplatin sensitivity in human head and neck squamous carcinoma cell lines. Cancer Lett 1994; 85:223-232.

30 Rotte A, Garmann D, Buss I, Jaehde U: Effect of extracellular ATP on cisplatin-induced cytotoxicity in human ovarian caner cells. Chemotherapy 2010;56:1-8. 
31 O'Driscoll L, Clynes M: Molecular markers of multiple drug resistance in breast cancer. Chemotherapy 2006;52:125-129.

32 Stavrovskaya AA, Stromskaya TP: Transport proteins of the $\mathrm{ABC}$ family and multidrug resistance of tumor cells. Biochemistry 2008; 73:592-604.

33 Kruh GD, Belinsky MG: The MRP family of drug efflux pumps. Oncogene 2003;22:75377552 .

34 Taniguchi K, Wada M, Kohno K, Nakamura T, Kawabe T, Kawakami M, Kagotani K, Okumura K, Akiyama S, Kuwano M: A human canalicular multispecific organic anion transporter (cMOAT) gene is overexpressed in cisplatin-resistant human cancer cell lines with decreased drug accumulation. Cancer Res 1996;56:4124-4129.
35 Ishikawa T, Ali-Osman F: Glutathione-associated cis-diamminedichloroplatinum(II) metabolism and ATP-dependent efflux from leukemia cells. Molecular characterization of glutathione-platinum complex and its biological significance. J Biol Chem 1993;268: 20116-20125.

36 Baumeister P, Reiter M, Schwenk-Zieger S, Welz C, Harréus U: Transforming growth factor-alpha reduces carcinogen-induced DNA-damage in mini-organ cultures from head and neck cancer patients. Mutat Res 2009;677:42-45.

37 Garcia R, Franklin RA, McCubrey JA: EGF induces cell motility and multi-drug resistance gene expression in breast cancer cells. Cell Cycle 2006;5:2820-2826.
38 Mandic R, Rodgarkia-Dara CJ, Krohn V, Wiegand S, Grénman R, Werner JA: Cisplatin resistance of the HNSCC cell line UTSCC-26A can be overcome by stimulation of the EGF-receptor. Anticancer Res 2009;29: 1181-1188.

39 Mandic R, Rodgarkia-Dara CJ, Zhu L, Folz BJ, Bette M, Weihe E, Neubauer A, Werner JA: Treatment of HNSCC cell lines with the EGFR-specific inhibitor cetuximab (Erbitux $\left.^{\circledR}\right)$ results in a paradox phosphorylation of tyrosine 1,173 in the receptor. FEBS Lett 2006;580:4793-4800.

40 Hynes NE, Lane HA: ERBB receptors and cancer: the complexity of targeted inhibitors. Nat Rev 2005;5:341-354. 